\title{
BILINGUALISM IN RUSSIA AND ITS IMPORTANCE IN SCHOOL EDUCATION: STATE OF THE ART REVIEW
}

\author{
Vida Yu. Mikhalchenko ${ }^{1}$, Elena A. Kondrashkina ${ }^{2}$, Svetlana V. Kirilenko ${ }^{3 *}$ \\ ${ }^{1}$ Prof. Dr., Head Scientific Researcher, Institute of Linguistics, Russian Academy of Sciences, \\ RUSSIA, vida-mi@mail.ru \\ ${ }^{2}$ Senior Scientific Researcher, Candidate of Sciences (Philology), Institute of Linguistics, Russian \\ Academy of Sciences, RUSSIA, e.kondrashkina@inbox.ru \\ ${ }^{3}$ Scientific Researcher, Candidate of Sciences (Philology), Institute of Linguistics, Russian \\ Academy of Sciences; Assoc. Prof., RUSSIA, svetlanavk@inbox.ru \\ ${ }^{*}$ Corresponding Author
}

\begin{abstract}
The article analyzes bilingualism in present-day Russia, giving a brief historical overview of its origin. The types of bilingualism that are peculiar to the Russian Federation are determined, and the question of the bilingual system existing in school education is considered. The demographic situation in a number of republics is analyzed, which is important as it largely determines the most common types of bilingualism in the Russian Federation. According to the data obtained from the scientific works, various sociological surveys, the 2010 population census and other sources, it is concluded that national-Russian bilingualism predominates and that Russian-nationalism is very insignificant. Since the majority of the republics are dominated by the Russian and Russian-speaking population, and the Russian language is a domineering language, Russians do not need to learn or use national state languages. The statistics of the 2010 AllRussian Population Census shows that practically all titular ethnic groups in the republics know Russian with figures reaching $90-98 \%$. The predominance of the Russian population creates a Russian-speaking environment, while the absence of a national-speaking environment is an additional factor in the language shift, i.e., the change of language. There has been an alarming trend towards the transition to Russian even in household communication and an increase in the proportion of those who consider it their native language. The family ceases to be a source of knowledge of the native language, as it used to be in the past, since only the older generation (grandmothers and grandfathers) can still speak their native language, and in most cases parents do not use it and cannot pass it on to their children. In such an environment, the school should become the main source of knowledge of native languages. Analyzing the situation in schools, we have to admit that instruction in native languages takes place, as a rule, in the primary grades of rural schools. In urban settings, subjects taught in national languages are virtually absent. In some regions of the Russian Federation such school subjects as national language and national literature are usually studied in national languages, while, according to scientists, it is already possible to teach such subjects as history, geography, labor, singing, and physical education in national languages of the republics. In this regard, the article analyzes the project 'Multicultural educational model of the Republic of Tatarstan', the concept of which is based on functional bilingualism and multilingualism. The authors come to the conclusion of the impossibility of bilingual school education in Russia at the present time.
\end{abstract}

Keywords: bilingualism, state languages, Russian language, national languages, types of bilingualism, school education, language change.

\section{OVERVIEW OF THE ROOTS OF BILINGUALISM IN RUSSIA}

Russia has historically been formed as a multinational state in which more than 100 indigenous peoples live, 
a number of ethnic groups and more than 150 languages function. The Finno-Ugrians were among the first nations that were brought under the Russian statehood, i.e. the Mordovians in the 15th century, the Mari people in 1552, then the Udmurts, as well as the Chuvashs and the Tatars. That happened in the middle of the XVI century. At the end of the XVI - beginning of the XVII centuries part of the Trans-Ural Bashkirs nation became part of Russia. At the end of the XVII century - the first half of the XVIII century the annexation of the Urals and Western Siberia was completed. The conquest of Siberia lasted from the XVI to the XIX centuries, in the XVIII century - of Chukotka and Kamchatka became parts of Russia. The annexation of other lands to Russia proceeded in different ways: the promotion of Russian Cossacks and service people onto the territory of these peoples, the construction of fortresses to guard against external enemies, voluntary entry into the Russian state in order to obtain protection and preferences from the Russian tsar, and in other ways. As a result, by the XX century in Russia, a huge number of people of different nationalities with different ethnic languages, both relatively developed and not even having a written language, turned out to be living side by side with Russians. In modern Russia the most numerous groups are the following seven peoples: Russians, Tatars, Ukrainians, Bashkirs, Chuvashs, Chechens and Armenians.

\section{INFLUENCE OF THE STATE ON THE LANGUAGE SITUATION}

The means of interethnic communication in the Russian Federation is the Russian language, which was first declared the state language in the Law of the RSFSR of October 25, 1991 'On the languages of the peoples of the RSFSR', then its status was enshrined in the Constitution of the Russian Federation in 1993 and in 2005 in the Law 'On the state language of the Russian Federation'. The Russian Federation (RF) consists of republics, territories, regions, cities of federal significance, an autonomous region, districts - all of them are equal subjects. Currently, in the Russian Federation there are 22 republics, 9 territories, 46 regions, 3 cities of federal significance, 1 autonomous region and 4 autonomous districts.

The overwhelming majority of the population speaks Russian; according to the 2010 census, it is $99.12 \%$. Each republic, from 1992 to 2014, adopted its own laws on languages. The first republics that adopted 'the Laws on the languages of the republics' were Buryatia, Komi, Tatarstan and Khakassia in 1992; the last one was the Republic of Crimea in 2014. In each of the republics, the Russian language and the languages of the titular nations became the state national languages, although in a number of republics the majority of the population was Russians at that time, and the representatives of the so-called titular ethnic groups constituted a small number of the population. Thus, the language situation of bilingualism was officially designated in the republics.

It is necessary to clarify the nomination 'titular language' and offer an explanation of what is meant by that before we move on. The term titular language denotes the language of the titular nation. This term has been applied since the beginning of 1990s in relation to the languages of the nations that gave their names to the corresponding republics of the Russian Federation (i.e. titular nations). For example, in the KarachayCherkess Republic, the title languages are the Karachai and Circassian languages. The actual status of the titular language gave certain advantages as opposed to 'non-titular' languages (as a rule, the languages of indigenous peoples living in this state entity), which later necessitated the development of legislation protecting the linguistic rights of citizens of the Russian Federation.

According to the adopted laws on languages, in most republics two languages are declared state languages, i.e. the Russian language and a national language, however there are some exceptions, namely: there are three state languages each in the Republic of Mari El (Mari mountain language, Mari meadow language, Russian language), in the Republic of Mordovia (Mokshan language, Erzyan language, Russian language), in Kabardino-Balkaria (Kabardian language, Balkarian language, Russian language), five state languages in the Karachay-Cherkess Republic (Abaza language, Karachai language, Nogai language, Circassian language, Russian language), fourteen languages in the Republic of Dagestan (Russian, Avar, Agul, Azeri, Dargin, Kumyk, Lak, Lezghin, Nogai, Rutul, Tabasaran, Tat, Tsakhur and Chechen languages). In the Republic of Karelia, 'the Law on Languages' has not been adopted and the legal status of languages has not been established. The linguistic life there is regulated by the Law 'On state support of the Karelian, Vepsian and Finnish languages' which was adopted in 2004.

\section{BILINGUAL LANGUAGE SITUATION CHARACTERISTICS}

In a bilingual language situation individuals' level of language competence is high, being it their native language or an acquired language, so that it provides the possibility for communication with representatives of another ethnos in one or more areas of communication, it also implies the practical use of both languages in the same linguistic community. Accordingly, a bilingual is 'a person who speaks two languages, of which the 'first language' (native language) is the language that is learned in childhood, in the family (as a rule, his 
ethnic language), the 'second language' is learned later (less often - simultaneously)' [DST, p. 30]. Bilingualism usually arises in a multiethnic society in the presence of linguistic contacts. This term can be applied when speajing of a whole language group or an individual. In this regard, the German scientist G. Kloss proposes to distinguish between 'national monolingualism, bilingualism and multilingualism', on the one hand, and 'individual monolingualism, bilingualism and multilingualism', on the other hand. A good example here can be Malta speakers, whose native language is Maltese, but many of the island's inhabitants also speak English or Italian. On the other hand, national bilingualism or multilingualism can be combined with individual monolingualism. So, in Switzerland, where there are four official languages, most of the population is monolingual and speaks only German, French, Italian or Romansh, depending on the region of residence.

From the point of view of sociolinguistics, bilingualism is the coexistence of two languages within one linguistic community, the use of these languages in various communicative spheres, depending on the social situation and other parameters of the communicative act. Both languages, serving a single language community, form a single socio-communicative system and are in a relationship of functional complementarity to each other. That leads us to the fact that bilingualism of a language group presupposes individual bilingualism of its members, but it does not mean that individual bilingualism is a consequence of the fact that this language community is bilingual.

There is an opinion that it is impossible to achieve absolutely equivalent proficiency in two languages, one language, usually a native one, will dominate another one, while there are exceptions when in different situations a bilingual person will use different languages.

In the modern world, both monolingualism and bilingualism are widespread. The latter is more widespread and some scientists, for example, Edwards believe that bilingualism is the norm, and monolingualism is an exception [Alpatov, 2017, p. 61] and as V.M. Alpatov pointed out, 'the choice between monolingualism and bilingualism is a choice between a full life and life in a closed language community' [Alpatov, 2013, p. 11].

\section{METHODOLOGY OF RESEARCH}

To obtain reliable data on the problem of bilingualism in the Russian Federation, the method of analysis of written sources is used, both from field work research in the republics, and statistical data from federal institutions. At the same time, the most recent data has been analysed in order to obtain the information on the state of bilingualism in Russia.

In the modern Russian Federation, there are both monolingual communities and bilingual ones. Russians can be classified as monolingual language community, especially those who live in regions where Russian constitute the majority of the population. Sometimes, in their entire lives, they never come across the need to use a language other than Russian (here we do not take into account tourist trips abroad).

In the republics, the situation has its own characteristics, associated primarily with the fact that for all schoolchildren Russian language is compulsory and at the same time schoolchildren have to study the national (native) language. The census of 2010 shows how this affects the level of competence in Russian and national languages. The percentage of those who speak Russian in some republics is as follows: Tatarstan - 97.3\%, Bashkortostan - 96.3\%, Mordovia - 99.4\%, Mari El - 95.6\%, Komi - 95.7\%, Khakassia $98.5 \%$, Altai $-96 \%$. At the same time, the percentage of those who speak the titular languages of these republics: Tatarstan - 52\%. Bashkortostan - 23.4\%, Mordovia - 23.6\%, Mari El - 30.9\%, Komi - 16.9\%, Khakassia - 7.6\%, Altai - 26\% [Language and society. Encyclopedia, pp 92 -93].

In the Russian Federation, in most national regions, representatives of the titular peoples are bilingual (sometimes multilingual). Russians, for the most part, do not know the local national languages. NationalRussian bilingualism is widespread in the Russian Federation, it can be also called 'one-sided bilingualism'. Russian-national bilingualism is not widespread. Before moving on it is necessary to clarify the difference between the two existing types of bilingualism: Russian-national bilingualism versus national-Russian bilingualism.

National-Russian bilingualism is a type of bilingualism on the territory of the Russian Federation (formerly the USSR), in which the first component of bilingualism, that is, the native language of the bilingual, is the socalled national language (any language of the country's autochthonous population, except Russian language), and the second component is Russian language itself. National-Russian bilingualism is a massive socially significant type of national bilingualism and is recognized as the most effective means of linguistic integration of a multi-ethnic community while maintaining the linguistic diversity of the country, since bilinguals, with the help of the means of interethnic communication throughout the country (i.e. Russian 
language), can also speak their native language. The share of bilinguals, for whom the second language is Russian language, differs in different regions of the Russian Federation, but in the whole country this figure exceeds $90 \%$, according to some estimates. Russian-national bilingualism, on the contrary, is a type of national bilingualism on the territory of Russia, in which the first component of bilingualism, that is, the native language of bilinguals is Russian, and the second component is the so-called 'national language' (that is, any ethnic language, except Russian language). Russian-national bilingualism is less widespread and exists mostly in the regions of Russia. These bilinguals are mostly not ethnically Russians, but they recognize Russian language as their mother tongue, while their ethnic language acts as the second component of bilingualism.

The 2010 census indicates that the number of Russians who speak the languages of the indigenous population is small and is widespread only among those individuals who graduated from national schools, lived for a long time among speakers of other languages, or needed to know a second language due to their official activities. So, in Tatarstan, $3.57 \%$ of Russians speak Tatar language, in Bashkortostan, Bashkir language is used by $1.02 \%$, in Mari El $1.45 \%$ speak Mari language, in Mordovia $1.02 \%$ speak Mordovian language, in Chuvashia 3.94\% speak Chuvash language, in Komi Komi-Zyryan languageis used by $2.04 \%$, in Sakha (Yakutia) Yakut language is used by $2.04 \%$, in the Republic of Khakassia $0.11 \%$ speak Khakass, in the Udmurt Republic Udmurt language is used by $1.26 \%$, in the Altai Republic $0,87 \%$ speak Altai language [Language and society. Encyclopedia, pp 92-93].

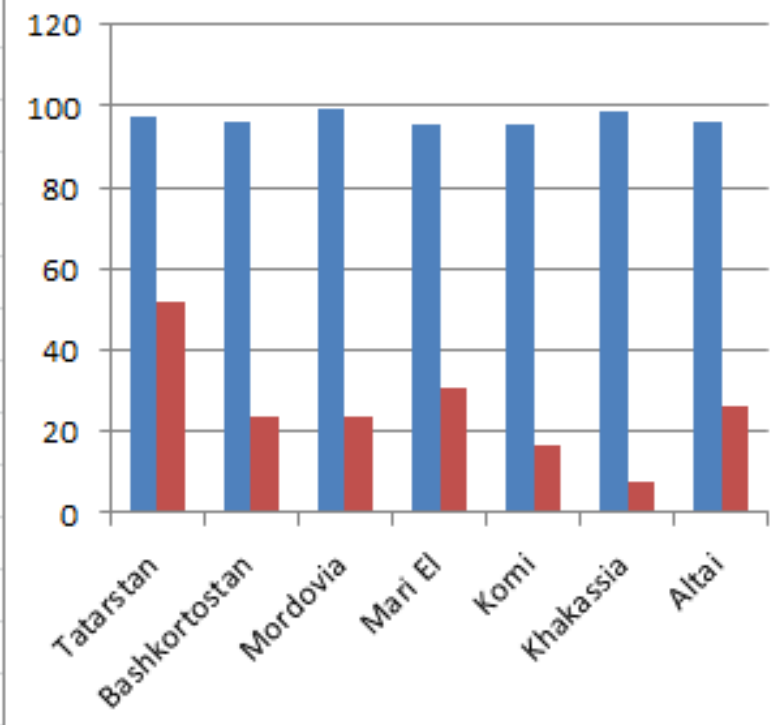

speaking Russian

speaking titular languages

Bilateral bilingualism exists when ethnic groups living in the same state or community learn each other's languages [Zamyatin, pp 12-13]. Bilateral bilingualism is commonplace in Russia as well. Finnish authors believe that, for example, in the Volga region, the Tatars, Chuvash, Mari and Udmurts even during the XX century had good level of proficiency in each other's languages. Besides, in the Yamalo-Nenets region and the former Dolgano-Nenets Autonomous Okrugs, the indigenous peoples traditionally knew each other's languages [Zamyatin, p. 12]. This type of bilingualism in the Russian Federation is called national-national, and it is common in some regions. For example, in the Republic of Bashkortostan, where Bashkirs and Tatars live in almost equal proportions, there have developed the following types of bilingualism, such as Tatar-Bashkir, Bashkir-Tatar, as well as Mordovian-Tatar, Chuvash-Tatar, etc. In the Republic of Mordovia, where the Tatars constitute the third largest group of the population after the Russians and Mordovians, Mordovian-Tatar and Tatar-Mordovian types of bilingualism have developed, especially in villages with a mixed population.

In the context of studying the Russian language at school, bilingualism begins to form at an early age, if the family uses not Russian, but the mother tongue (national language). But nowadays, the family has almost ceased to be the transmitter of the language to the next generations. In these conditions, the role of school education in the national language is growing.

However, in most cases, the mother tongue is only the language of instruction, and not the medium using which the teaching takes place. This is especially true for urban schools: as a rule, a national language is taught as a foreign language for 2-4 academic hours a week. After leaving the school, students find themselves in a Russian-speaking environment and communicate with each other and with friends, also in 
Russian language. The lack of a linguistic environment is one of the main threats to the preservation of national languages. In rural areas, in some regions, the situation is more optimistic, but even then only in those villages where the majority of speakers are the representatives of a titular nation. In such places, national language is used as a means of instruction in most cases only in primary school. So, according to the data for the $2017 / 2018$ academic year, a total of $14,043,396$ children studied at state educational institutions. 13896175 pupils used Russian as a means of teaching. The number of children using national languages as a means of education was 258453 people, as a subject - 1547745 people. As a means of instruction, 28 languages were used, and as a subject - 72 languages [Goryacheva, p. 21]. In the conditions when only two disciplines are taught in national languages in schools - language and literature, it is impossible to talk about a comprehensive study of the native language. Back in 2005, at a conference dedicated to the 85th anniversary of the statehood of the Udmurt Republic, the Hungarian scientist F. Laszlo said that if chemistry and physics are difficult to be taught in the Udmurt language, then history, geography, music, drawing, physical education lessons can be held completely in Udmurt-language [Feyesh, p. 347].

Population censuses show that the number of those who consider Russian to be their native language is constantly growing. So, scientists from the republics with the Finno-Ugric population write that according to the 2010 census, Russian was called as their native language by the following number of speakers: $37.1 \%$ of Komi in Komi (excluding Komi-Perm), 72.7\% - Karelians in Karelia, $43.9 \%$ - Udmurts in Udmurtia, 20.2\% Mari in Mari El and 18\% - Mordovians in Mordovia [Shabaev, p. 64].

In order to raise the prestige of the state national languages in some republics (Tatarstan, Bashkortostan, Finno-Ugric republics), in the early 2000s, their compulsory study was introduced for all students, regardless of their nationality and desire, which caused a sharp discontent among the parents of Russian students. At the same time, the number of Russian language lessons has decreased. Rallies, meetings, appeals of Russian citizens against the innovation began, tension increased. The question of compulsory and voluntary language learning was a burning issue. The intervention of the president was required. Speaking at a meeting of the Presidential Council on Foreign Relations on July 20, 2017 in Yoshkar-Ola, Vladimir Putin said: 'For us, the Russian language is the state language, the language of interethnic communication, and it cannot be replaced by anything, it is the natural spiritual framework of our entire multinational countries. Everyone should know it. The languages of the peoples of Russia are also an integral part of the original culture of the peoples of Russia. Learning these languages is a constitutionally guaranteed right, a voluntary right. Forcing a person to learn a language that is not native to him is also unacceptable, as well as reducing the level and time of teaching Russian' [Khaliulina, p. 394].

In such a situation, it makes no sense to discuss the question of bilingual education, since there are no prerequisites for it. Students master the Russian language, but do not want to learn their native language, as they do not see the prospects for its use in the future. Therefore, school education in Russia is, in fact, monolingual. In this regard, an interesting initiative has been put forward by the Institute of History. Sh. Mardzhani, having developed the project 'Multicultural educational model of the Republic of Tatarstan', the concept of which is based on functional bilingualism and multilingualism [Lotfullin, p. 100]. The principle of multilingualism: this is when a multilingual person speaks several languages, which is determined by the trend of integration, the dialogue of cultures and the expansion of intercultural communication. Functional bilingualism implies teaching simultaneously some subjects in a native language, some subjects in Russian at different educational levels. For example, in the native language there is a greater number of lessons at the initial stage of education. In the secondary school, along with Russian and native languages, foreign languages can be also taught [Lotfullin, pp 101-103].

\section{CONCLUSION}

Based on the conducted research of various sources, statistical data and the opinion of scientists, the following conclusions can be drawn: despite the fairly widespread national-Russian bilingualism in Russia, conditions for bilingual education still do not exist. The Russian language dominates in almost all spheres of communication, and an increasing number of young people choose it for their future careers, since, from the Unified State Exam to higher education, everything is in Russian. Lack of motivation to learn a native language is an important argument in favour of the Russian language, because, even after mastering the native language, the question arises - where can you apply your knowledge? Only being a language teacher at school or university at the Faculty of Philology. But not all school graduates have a desire to be engaged in teaching activities. In this regard, the republics should pursue a language policy that would raise the prestige of the national language, the desire to know it and be proud that the language is the same symbol of statehood as it is the flag or the anthem. 


\section{ACKNOWLEDGEMENT}

The reported study was funded by RFBR and DFG, project number № 21-512-12002 HHИO_a "Prognostic methods and future scenarios in language policy - multilingual Russia as an example"

\section{REFERENCE LIST}

Alpatov, V.M. (2013) Language policy in the modern world: "monolingual" and "bilingual" practices and the problem of language assimilation // Comparative politics, No. 2 (12), Moscow. pp 11-22

Alpatov, V.M. (2017) Monolingualism and multilingualism // Solving national and linguistic issues as a factor in strengthening the security of Russia. Moscow. pp 60-65.

DST: Dictionary of Sociolinguistic Terms (2006). / Mikhalchenko, V.Yu. (ed.) Moscow: Institute of Linguistics, Russian Academy of Sciences.

Feyesh, L. (2006) Possible ways of preserving the Udmurt language: a view from the outside // Problems and prospects of the functioning of native languages. Izhevsk. pp 346-350.

Goryacheva, M.A. (2018) Dynamics of the use of the languages of the peoples of the Russian Federation in the field of education over the past decade in the context of sociolinguistic problems // Voprosy philologii, no. 1 (61). Moscow. pp 20-26.

Kondrashkina, E.A. (2016) Bilingualism and Diglossia // Language and Society. Encyclopedia. Moscow. pp 88-94.

Khaliulina, A.I. (2014) The problem of teaching native languages in schools of Bashkortostan // Linguistic unity and linguistic diversity in a multiethnic state. International Conference. Moscow, November 1417, 2014 Moscow. pp 393-401.

Language and society. Encyclopedia. Moscow (2016) 872 c. ISBN 978-5-91172-129-9

Lotfullin, M.V. (2017) Multicultural educational model of the Republic of Tatarstan: stages of implementation // D. Muller, M. Wingender (ed.) Multilingualism in the Volga-Ural region. Volume 1. Actual language policy and language situation. Frankfurt am Main. pp 101-112.

Mikhalchenko, V.Yu., Kozhemyakina, V.A. (2016) Methods of sociolinguistic research // Language and society. Encyclopedia. Moscow. pp 282-285.

Mikhalchenko, V.Yu. (2016) Language situation and language policy in modern Russia // Language and society. Encyclopedia. Moscow. pp 5-16.

Oreshkina, M.V. (2016) Language legislation in the Russian Federation // Language and society. Encyclopedia. Moscow. pp 835-847.

Results of the 2010 All-Russian Population Census in 11 volumes (2012). Moscow, Research Center 'Statistics of Russia', Vol.4. Book 1. 2101 p.

Shabaev, Yu.P., Vorontsov, V.S., Orlova, O.V., Martynenko, A.V., Mironova, N.P. (2018) Language policy and language orientations of the population in national republics: a conflict of interests between groups or imperfection of cultural practices (on the example of regions with a Finno-Ugric population)? // Voprosy philologii № 1 (61), Moscow. pp 62-74.

Zamyatin K., Pasanen A., Saarikivi J. (2012) How and why should the languages of the peoples of Russia be preserved? Helsinki.179 $\mathrm{p}$. 